\title{
Solution Oriented Entrepreneurship as an Alternative Public Relations Practice
}

\author{
Alternatif Bir Halkla İlişkiler Uygulaması Olarak Çözüm Odaklı \\ Girişimcilik \\ Simge ÜNLÜ KURT*
}

\begin{abstract}
Solution-oriented entrepreneurship, which can be defined as a kind of non-profit initiative, refers to the whole of organizations that mission themselves to produce innovative solutions to ongoing social problems. The structure of solution-oriented initiatives proposed as a new field of practice for public relations is different from other public relations practices in terms of their mission and functions. In the study, suggestions will be made on how relations with the people with different practice fields such as image management, lobbying, crisis communication and relationship management can institutional solution-oriented entrepreneurship as a practice domain and develop the domain of influence in this way. In fact, solution-oriented entrepreneurship is thought to play an important role in the formation of social impact, which is one of the main goals of public relations, as the driving force of sustainable and economic development.
\end{abstract}

Keywords: Public Relations, Entrepreneurship, Solution-Oriented Entrepreneurship, Social Impact.

$\ddot{O} z$

Kar amacı gütmeyen bir girişim türü olarak tanımlanabilecek çözüm odaklı girişimcilik, süregelen toplumsal sorunlara ilişkin yenilikçi çözümler üretmeyi kendine misyon edinen kuruluşlar bütününü ifade etmektedir. Halkla ilişkilere yeni bir uygulama alanı olarak önerilen çözüm odaklı girişimlerin yapısı diğer halkla ilişkiler uygulamalarından gerek misyonu gerekse de işlevleri açısından farklılıklar arz etmektedir. Çalışmada imaj yönetimi, lobicilik, kriz iletişimi ve ilişki yönetimi gibi farklı uygulama alanlarına sahip halkla ilişkilerin, çözüm odaklı girişimciliği bir uygulama alanı olarak kendi bünyesine nasıl dahil edebileceği ve bu yolla etki alanını geliştirebilmesi için öneriler sunulacaktır. Öyle ki, çözüm odaklı girişimcilik sürdürülebilir ve ekonomik kalkınmanın lokomotifi olarak halkla ilişkilerin de asli amaçlarından biri olan sosyal etkinin oluşturulmasında önemli bir rol oynayabileceği düşünülmektedir.

Anahtar Kelimeler: Halkla İlişkiler, Girişimcilik, Çözüm Odaklı Girişimcilik, Sosyal Etki.

\section{Introduction}

Non-profit organizations are making sustainable development permanent through entrepreneurship to facilitate the attribution of social issues and ideas to society. These organizations, who act voluntarily in the creation of social value, strive to provide social benefits by developing an entrepreneurial perspective on social problems. Public relations, on the other hand, is working for the same purpose through institutional social responsibility and sponsorship activities. Although public relations and the entrepreneurship activities of nonprofit organizations do not show any closeness in the context of practice processes and strategies, solution-oriented entrepreneurship has the qualities that can be put into public relations discipline as a practice field.

Entrepreneurship is not only a process directed by businesses that act individually but also a phenomenon involving the entire society beyond business ownership (Thompson, 1999, p. 209). It is the main source of social transformations, such as economic growth, improvement of health services and employment creation. This transformation is made to unite and convince people of common benefit by referring to environmental, health, technological or repressive causes against national boundaries. In other words, entrepreneurship, by carrying out worldwide actions to improve the quality of life and strengthen social positions, is able to eliminate boundaries and strengthen people economically with these entrepreneurship activities. Public relations, on the other hand, is responsible for creating mutual benefits and social impact as an extension of the excellent public relations understanding with the activities

\footnotetext{
*Arş.Gör. Dr., Sakarya Üniversitesi, İletişim Fakültesi, simgeunlu@ sakarya.edu.tr 
carried out by the social citizenship mission on behalf of the organization in which they are affiliated or on behalf of.

In this study, first of all, the literature on entrepreneurship and entrepreneurial process will be presented and then solution-oriented entrepreneurship, which is proposed as a new field of practice for public relations, will be transferred along with its objectives, structure and operational processes.

\section{The Concept of Entrepreneurship and Entrepreneurship Process}

The term entrepreneurship was first introduced by French economist Jean Baptiste Say in the $18^{\text {th }}$ century in the light of the developments in the industrial revolution. The French economist defined the term entrepreneur as a person who created an idea and economic value for an important project or activity that would bring economic resources to the next level. More specifically, entrepreneurs are people who do something new for the development of the economy and find new business areas for technological growth and social transformation (Dees, 1998, p.2).

With the transition from industrial society to information society, entrepreneurship has started to be managed by change agents (Thompson, 1999, p. 209-210). Josephn Schumperter (1949), one of the most important economists of the $20^{\text {th }}$ century, described entrepreneurship as catching innovation, assessing opportunities and starting operations with the purpose emerged as capitalism's 'creative-destructive' process. In this context, entrepreneurship serves through change agents to find new markets and innovative solutions to move the economy forward.

According to Peter Drucker, the management Guru, entrepreneurship is to seek ways to change, to develop methods that are appropriate for this change, and to benefit from the emerging situation as an opportunity. Drucker, however, states that starting a job is not sufficient in terms of entrepreneurship; rather, it is necessary to have a mindset that can see the possibilities caused by a problem rather than the emergence of a problem (Dees, 1998, p. 3). In this context, entrepreneurs are engaged in activities to implement the innovation process. Therefore, entrepreneurship can be considered as a growing dynamic of the economy in which problems are solved, opportunities are explored and resources are brought together in order to create value. This dynamic, taking advantage of both systematic and positive changes, is transforming significantly by improving the exposed wound of society (Reynolds, Storey \& Westhead, 1994, p. 443).

In addition to being aware of opportunities, entrepreneurship also requires effective use of these opportunities. The presence of individual groups is an important value in the entrepreneurial work to assess opportunities, discovery processes, seize the opportunities and to make effective use these opportunities. Since individual groups acting in line with their own initiatives bring innovative solutions to social, industrial and environmental problems in order to achieve business profits (Shana and Venkataraman, 2000, p. 217-226). Entrepreneurship, a combination of risk and innovation process, is a management of a business initiative to make profit. The point to note here is that all businesses and business management owners are not actually entrepreneurs (Tan et al., 2009, p. 356). In other words, what constitute the dynamics of the initiative are individuals or businesses undertaking economic roles by taking part in a business plan process to create employment and provide social change. 


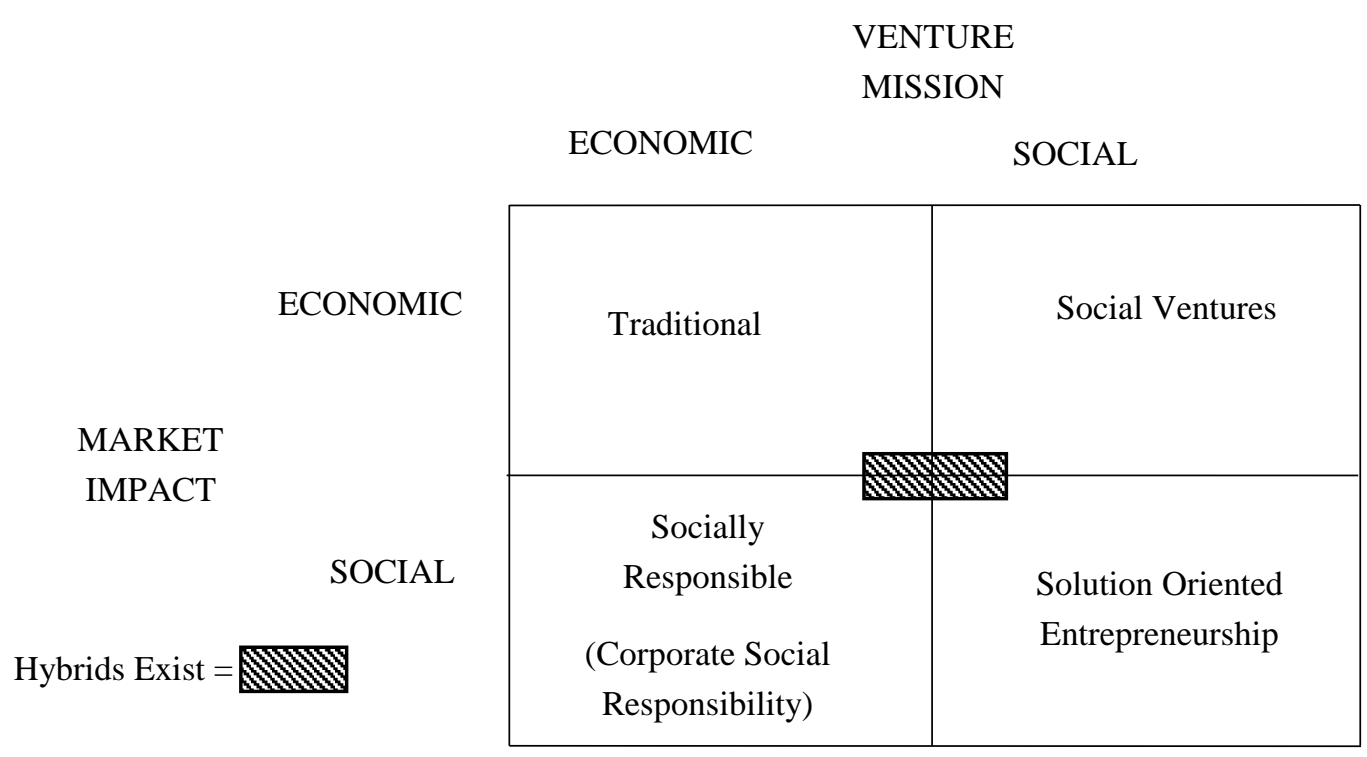

Figure 1:Venture of Typology

Source: Neck etc., 2009, p. 15

When the entrepreneurship process is examined, it is noted that there are characteristic, environmental and sociological elements that affect this process. In the entrepreneurial process model (Figure 2), the advantages derived from the entrepreneur's personal characteristics, financial resources, cultural elements and social networking connections directly affect the functioning of the process (Zacharakis etc, 2010, p. 49).

- Innovation phase; technical knowledge acquisition, making initiative ideas important, looking for a suitable place for business opportunity,

- Finding physical and human power through the development of connections at the practice level, customer portfolio creation, service of market products and production process,

- At the stage of development (growth), the process of organizing is discussed in order to respond to the needs of the government and society.

The fact that the first stage of entrepreneurship is a linear process that begins with the decision of entrepreneurship and the model where the elements that take part in different stages of this process are brought together are shown below.

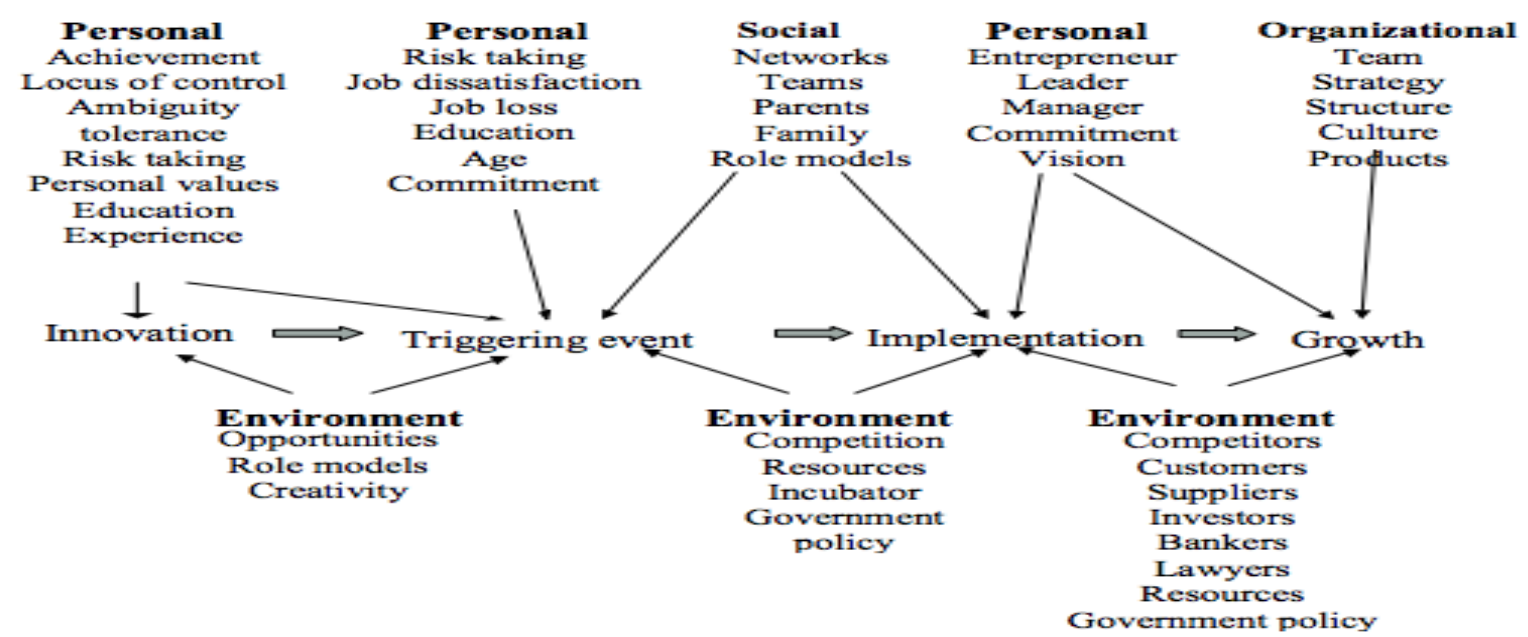

Figure 2: Model of the Entrepreneurial Process

Source: Bygrave, 2004, p.3. 


\section{Solution-Oriented Entrepreneurship and Public Relations}

Civil society covers all types of voluntary groups that have been institutionalized or noninstitutionalized. The organized and institutionalized form of civil society is expressed as the non-governmental organization (NGO). NGOs are non-profit organizations that work on a voluntary basis for the benefit of their members and supporters or the whole community. In theory, NGOs are organizations that are outside the hierarchical management of the state, that do not take orders from state institutions and work for the welfare and the well-being of the society for a purpose that does not interfere with political parties and does not give direct benefit to them; and they are also defined with the terms such as third sector, non-profit sector, voluntary sector and charity sector (Özden, 2008, p.15-16). The sector in which public relations continue to exist is seen as profit-oriented organizations and the discipline practice areas are designed in accordance with the structure of this sector.

In fact, social marketing, promotional activities or services such as financial public relations stand out as activities that serve the purposes of the private sector. However, out of this sector, public relations activities are restricted and employees are required to carry out their duties as pure promotion departments. When assessed from a different perspective, practices such as image-reputation studies, crisis management, lobbying and event management, due to their nature, are directly linked to the organization and serve as an extension of its aims. Unlike the practices listed above, social responsibility and sponsorship areas are the practices that the institution uses to fulfill its social goals and make it necessary to establish close relations with external stakeholders; however, they have the attribute of supporting social elements that need to be resolved or improved to a social problem and are also indirectly viewed as activities that are applied to correct and improve the organization's target audience perception. The study is based on the assessment of the practice areas of public relations in this context and based on the question "can an alternative practice area contribute to public relations?" that appears in the mind. In response to this question, solution-oriented initiative has been considered as one of the most powerful elements. Thus, although the concept is understood by its name as the initiative activities of non-governmental organizations, when examined in detail, it covers all of the social initiative processes which are not limited to non-governmental organizations and which can be applied to different sectors.

Therefore, although the study progresses specific to non-governmental organizations, it is foreseen that other sectors can carry out solution-oriented entrepreneurship through support of entrepreneurs. Here, the question "what is the difference between sponsoring a civil society initiative and supporting a civil society initiative directly?" is considered solution-oriented entrepreneurship as the most important determinant in offering public relations as a practice area.

Public relations fundamentally involve the processes of recognition and promotion, and in essence, it requires the recognition of the environment and self-introduction to the environment. In this respect, public relations policies determine the opinions and suggestions of the people in which the organization is in relation, as well as introducing the organization to the environment (Işık and Erdem, 2007, p.115). However, when we move a tiny bit out of this approach, it can be seen that the responsibility of the organization to fulfill its social and environmental responsibilities can be seen through its activities such as institutional social responsibility and sponsorship. Solution-oriented entrepreneurship, however, involves promoting and directing institutional social responsibility and sponsorship activities and individuals -regardless of scope and size- by taking one step further away from institutional social responsibility and sponsorship activities, by addressing the processes of providing labor, time and equipment or providing financial support with an integrated approach. 
Solution oriented entrepreneurship assumes that, in addition to protecting human rights and freedoms in which society can co-exist, regardless of differences in nation, religion and politics, it will bring people together around issues such as helping people in need, extending the hand of help and protecting the environment (Y1ldirım, 2004, p. 54). Here, entrepreneurship, which can be seen as a key concept, includes different solution proposals within the structure of innovation and dynamism. Therefore, this is seen as the priority issue of the present social problem, which requires business partnerships with the public sector and distinguishes solutionoriented initiatives from long-term social responsibility practices. Thus, the orientation of individuals and groups with the spirit of initiative, which is directly derived from the initiative or promoted from external stakeholders by public relations practitioners, with a focus on social change, has the ability to bring an innovative approach to public relations practices.

In the process of generating innovative solutions to social problems, new resources are constantly being sought to gain social capital as well as to provide social benefits. This search for resources and the delay of solutions causes the sensitivity of society towards the subject to increase day by day (Güler, 2010, p. 42-43). Although institutional social responsibility activities are seen as effective in solving social problems, the aims cannot be achieved due to experienced economic, political and social problems as well as long-term processes. However, institutional social responsibility activities do not have a concern about bringing "innovative" solutions, but they are only aimed at solving the social problem in the context of the project. Therefore, solution oriented entrepreneurship is seen as an element that can bring a different approach to public relations practices where new ideas and practices are used effectively.

Members and volunteers are considered to be the most effective elements for the solution of social problems. This is a difficult process to produce solutions to social problems without them. Although non-governmental organizations carry out solution oriented studies within their own fields, they have difficulties in reaching a sufficient number of members and volunteers (Özden, 2008, p. 58-59). The main problem is that the solution proposals and the organization established around this proposal do not have the ability to communicate and promote. Another important element in the assessment of solution-oriented entrepreneurship as a field of practice of public relations is seen here. A solution oriented initiative led by public relations and consultancy is considered to be an element that can ensure high efficiency in both promotional activities and communication with stakeholders and target audiences.

Social, political, legal and economic structural transformations are required for an environment where solution oriented initiatives will gain full functionality and be accepted. The public relations activities that plan and carry out these transformations under current conditions will accelerate solution-oriented initiatives and it is also important to ensure the scope and impact of individuals and organizations that aim to bring solutions to social problems (Biber, 2006, p.6). The effective use of mass media in solution oriented entrepreneurship activities directed by public relations is of utmost importance. In this context, publicity for the public is required to be supported and communicated with tools that will make effective in terms of sustainability of solution oriented entrepreneurship activities. 


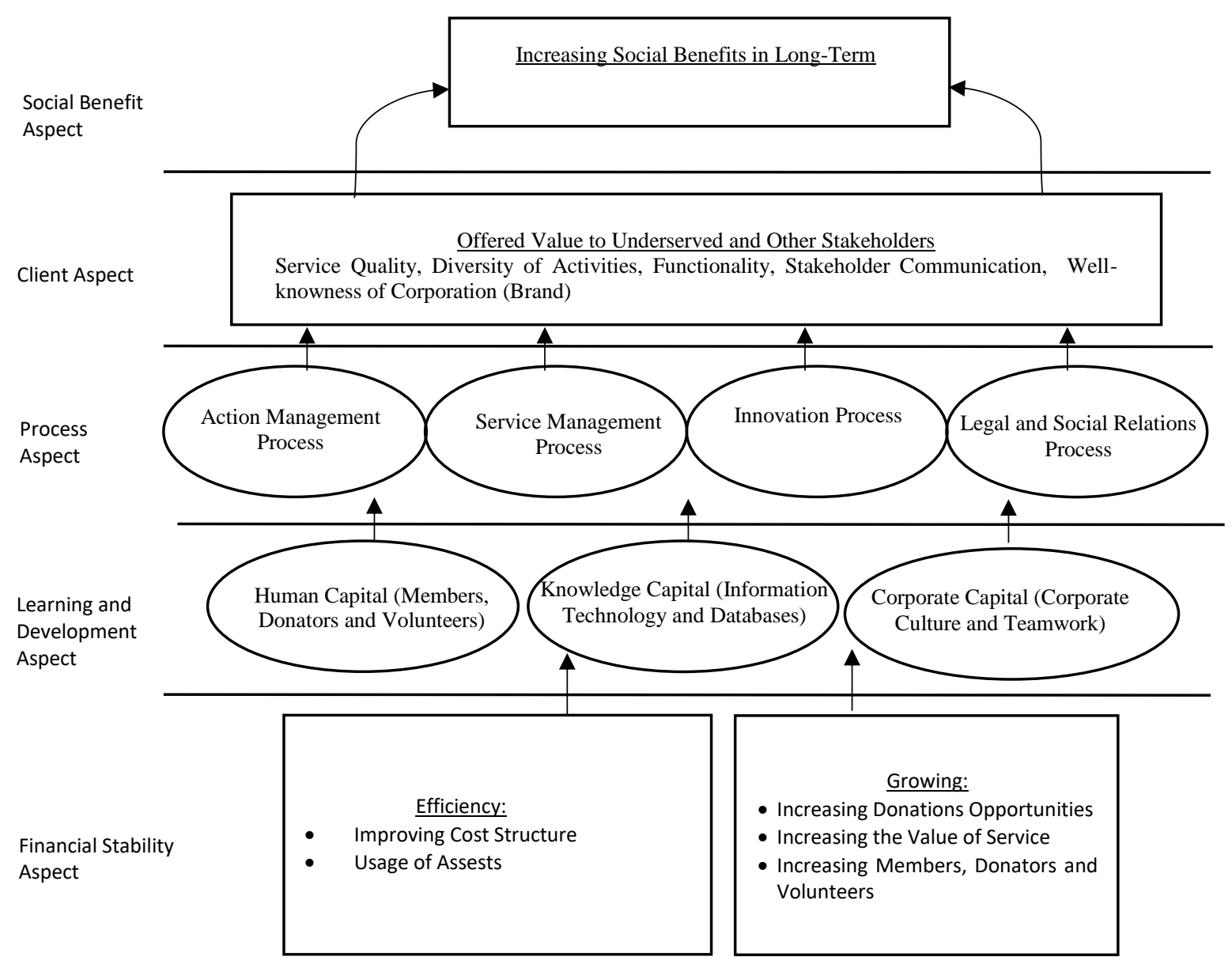

Figure 3: The Case of Strategy Map Social Oriented Entrepreneurs

Source: Coşkun, 2006, p. 111.

In order for the solution-oriented initiatives to realize their mission, it is necessary to determine the extent to which they have achieved their management goals and the strategic goals that are their foundation purposes. In this respect, the visionary structure and selfassessment competence of solution-oriented initiatives as a field of practice of public relations are of great importance. Thus, this missionary structure and assessment competence is one of the most important reasons to classify solution oriented initiatives as an activity under public relations. In this context, there are performance criteria to measure whether solution oriented entrepreneurship activities of non-governmental organizations have achieved the specified objectives. Accordingly, human capital, information capital and institutional capital, which are located in the learning and development dimension of the strategy map in Figure 3, constitute the infrastructure of the institution. Performance in these areas, is a prerequisite for improving the performance of the institution's processes. The increase in value offered to service areas and other stakeholders is also dependent on the performance of processes, activities, service areas, innovations and legal processes. Increasing the social benefit to the society in the dimension of social benefit in the long run, good communication with stakeholders and the reputation of the organization (brand) depend on increasing the values that are presented to service receivers and other stakeholders. The financial dimension, which is at the top of the strategy map in profitable initiatives, is at the bottom of the strategy map of solution oriented initiatives (Coşkun, 2006, p. 111-112). 


\section{Conclusion}

In this study, the importance of solution oriented initiatives proposed as a practice area of public relations is increasingly attached to the increase in the number of initiatives, as well as the expansion of efforts for the development of civil society in the political, cultural and economic environment.

Social life is shaped by the entrepreneurship practices in which many individuals interact continuously and interact with each other through social networks. In fact, these social systems also serve the purposes of increasing social awareness and changing social structure in the process of public establishment. However, the assessment of the benefit of collective action plays an important role in the production, receiving and processing of information. The solution oriented initiatives that are organized to influence and direct the public are the most important tools and require the most effective use of them in order to realize entrepreneurship, which is naturally the elements of the social system. The element to realize this process is the existence of public relations as a managerial element.

In today's societies, the good functioning of public spaces depends primarily on the levels of collective organization of these societies. In a sense, initiatives also assume the role of shaping the public opinion. Therefore, it is possible to accept solution oriented initiatives as a social mechanism that fulfills the functions of informing and shaping societies through public relations.

As a result, it is considered that public relations can be an ideal channel for increasing access and effectiveness of organizations in developing innovative solutions to social problems. These solution oriented initiative practices and can also help to enable social participation mechanisms in this process.

\section{References}

Bygrave, W. D. (2004). The entrepreneurial process. In W. D. Bygrave \& A. Zacharakis (Eds.). The portable mba in entrepreneurship. Hoboken, NJ: John Wiley \& Sons.

Biber, A. (2006). Sivil toplum örgütlerinde halkla ilişkiler. Ankara: Nobel Yayın Dağıtım.

Coşkun, A. (2008). Sivil toplum kuruluşlarında performans esaslı yönetim, 27-40. İçinde: sivil toplum kuruluşlarında yönetim (Ed: Ali Coşkun). Ankara: Seçkin Yayıncılık.

Dees, J.G. (1998). The meaning of social entrepreneurship.

Güler, B. K. (2010). Sosyal girişimcilik, Ankara: Efil Yayınevi.

Işık, M. \& Erdem, A. (2007). "meşruiyet, demokrasi, sosyal sorumluluk ve halkla ilişkiler", tüm yönleriyle halkla ilişkiler ve tanıtım, (Ed:Metin Işık), Konya: Eğitim Kitabevi,

Neck H., C. Brush \& E. Allen (2009). 'The landscape of social entrepreneurship'. Business Horizons, 52, 13-19.

Özden, K. (2008). Sivil toplum ve sivil toplum kuruluşları, 11-25. içinde: Sivil toplum kuruluşlarında yönetim (Ed: Ali Coşkun). Ankara: Seçkin Yayıncılık.

Reynolds, P.D., Storey, D., \& Westhead, P. (1994). 'Cross-national comparisons of the variation in new firm formation rates'. Regional Studies: The Journal Of The Regional Studies Association, 28(4), 443-456.

Shane, S. \& Venkataraman, S. (2000). 'The Promise of entrepreneurship as a field of research'. Academy Of Management Review, 25(1), 217-226.

Schumpeter, J. A. (1949). Theory of economic development, Harvard University

Press: Cambridge, Massachusetts.

Tan, W. L., Williams, J., \& Tan, T. M. (2005). Defining the 'social'in 'social entrepreneurship': altruism and entrepreneurship. The International Entrepreneurship and Management Journal, 1(3), 353-365. 
Thompson, J. L. (1999). The world of the entrepreneur-a new perspective. Journal of workplace learning, 11(6), 209-224.

Yıldırım, İ. (2004). Demokrasi sivil toplum kuruluşları ve yönetişim. Ankara: Seçkin Yayıncilik.

Zacharakis, A., Bygrave, W., \& Corbett, A. C. (2010). Entrepreneurship. 